\title{
Effect of a High-Fat Diet on 24-Hour Pattern in Expression of Prolactin and Redox Pathway Enzymes in the Rat Adenohypophysis
}

\author{
Pilar Cano ${ }^{1}$, Daniel P. Cardinali ${ }^{*}, 2$, Vanesa Jiménez-Ortega ${ }^{1,}$ María J. Ríos-Lugo ${ }^{1}$, Pablo A. Scacchi ${ }^{2}$ \\ and Ana I. Esquifino ${ }^{1}$ \\ ${ }^{I}$ Department of Biochemistry and Molecular Biology III, School of Medicine, Universidad Complutense, Madrid 28040, \\ Spain \\ ${ }^{2}$ Department of Teaching and Research, Faculty of Medical Sciences, Pontificia Universidad Católica Argentina, 1107 \\ Buenos Aires, Argentina
}

\begin{abstract}
The effect of a high-fat diet (35\% fat) on 24-h changes in expression of prolactin and redox pathway enzyme genes was examined in the anterior pituitary of male rats. When body weight of high-fat fed rats attained values about 20$25 \%$ higher than controls (after 66 days of treatment) animals were sacrificed at 6 different time intervals throughout a 24-h cycle. Anterior pituitary mRNA levels were measured by real-time PCR analysis. In control rats expression of the prolactin gene peaked in anterior pituitary at early scotophase, $3 \mathrm{~h}$ in advance to the peak in plasma prolactin levels. In high-fat fed rats this correlation was lost. A disruption of 24-h rhythmicity of pituitary gene expression of heme oxygenase (HO)-2, Cu/Zn- superoxide dismutases (SOD), Mn-SOD, catalase, glutathione peroxidase (GPx) and glutathione reductase (GR) was apparent in high-fat fed rats. Anterior pituitary mRNA levels for nitric oxide synthase (NOS)-2 and HO-2, Cu/Zn- and Mn- SOD and catalase augmented in high-fat fed rats, whereas those of GPx and GR decreased. The results indicate a disrupted coordination between prolactin gene expression and prolactin release in highfat fed rats that comes along with a disturbed expression of redox enzyme genes in the anterior pituitary.
\end{abstract}

Keywords: High fat diet, circadian rhythms, gene expression, anterior pituitary, prolactin, nitric oxide synthase, heme oxygenase, superoxide dismutase, catalase; glutathione peroxidase, glutathione reductase.

\section{INTRODUCTION}

In a recent study we reported the disrupting effect of a high-fat diet (35\% fat) on 24-h changes of anterior pituitary hormones including prolactin, luteinizing hormone and thyroid stimulating hormone [1]. A significant alteration of the circadian apparatus in rats fed a high-fat diet may occur, as shown by the disruption of pineal melatonin and plasma corticosterone daily rhythms, two important circadian signals [2].

As a continuation of that study, we undertook the present experiments to analyze the correlation of 24-h expression of prolactin gene in anterior pituitary with the daily secretory profile of prolactin in rats fed a high-fat or a normal diet. Since redox enzymes are involved in prolactin secretory mechanisms $[3,4]$ we wished to correlate the possible changes in prolactin secretion with gene expression of nitric oxide (NO) synthase (NOS), heme oxygenase (HO), superoxide dismutases (SOD), catalase, glutathione peroxidase (GPx) and glutathione reductase (GR) in the anterior pituitary. Overall we wished to assess whether a disruption in coordination of prolactin gene expression and prolactin release occurs in high-fat fed rats along with a disturbed expression of pituitary redox enzyme genes.

*Address correspondence to this author at the Department of Teaching and Research, Faculty of Medical Sciences, Pontificia Universidad Católica Argentina, 1107 Buenos Aires, Argentina; Tel/Fax: 5411 43590200, Int. 2310; E-mail: danielcardinali@uca.edu.ar, danielcardinali@fibertel.com.ar

\section{MATERIALS AND METHODOLOGY}

Male Wistar rats (45 days of age) were maintained under standard conditions with controlled light (12:12 h light/dark schedule; lights on at 08:00 h) and temperature $(22 \pm 2 \mathrm{C})$. Rats were divided into 2 groups: (a) normal diet ad libitum. (b) high-fat diet ad libitum. Both control (4\% fat) and highfat (35\% fat) diets were obtained from Harlan Iberica, Barcelona, Spain. The characteristics of the diet employed are summarized in Table 1. Individual daily food intake was $17 \pm 1 \mathrm{~g}$ (normal diet) and $19 \pm 1 \mathrm{~g}$ (high-fat diet).

Table 1. Diet Composition and Consumption

\begin{tabular}{|c|c|c|}
\hline & Control & High-Fat Diet \\
\hline \hline \% Fat & 3 & 35 \\
\hline \% Carbohydrates & 60 & 35 \\
\hline \% Protein & 16 & 20 \\
\hline \% Vitamins and minerals & 21 & 10 \\
\hline Caloric content (Kcal/g) & 2.9 & 5.4 \\
\hline $\begin{array}{c}\text { Consumed fat } \\
\text { (Kcal/day/animal) }\end{array}$ & 4.86 & 56.7 \\
\hline $\begin{array}{c}\text { Consumed carbohydrates } \\
\text { (Kcal/day/animal) }\end{array}$ & 43.2 & 25.2 \\
\hline $\begin{array}{c}\text { Consumed protein } \\
\text { (Kcal/day/animal) }\end{array}$ & 11.5 & 14.4 \\
\hline
\end{tabular}


After 66 days of treatment body weight was $492.5 \pm$ $60.1 \mathrm{~g}$ (high-fat diet) and $397.5 \pm 73.6 \mathrm{~g}$ (normal diet). At this time rats were sacrificed by decapitation under conditions of minimal stress at 6 different intervals ( 8 rats per group), every $4 \mathrm{~h}$ throughout a $24-\mathrm{h}$ cycle, starting at 09:00 h. At night intervals animals were killed under red dim light. The brains were rapidly removed and the anterior pituitary was dissected out. Tissues were kept frozen at $-70 \mathrm{C}$ until further assayed. The care and use as well as all procedures involving animals were approved by the Institutional Animal Care Committee, Faculty of Medicine, Complutense University, Madrid. The study was in accordance with the guidelines of the Institutional Care and Use Committee of the National Institute on Drug Abuse, National Institutes of Health and the Guide for the Care and Use of Laboratory Animals [5].

Total anterior pituitary RNA extraction was performed using the RNeasy protect mini kit and was analyzed using QuantiTec SYBR green kit (Qiagen, Hielden, Germany). The iScript ${ }^{\mathrm{TM}}$ cDNA Synthesis Kit (Bio-Rad Laboratories $\mathrm{SA}$; Madrid) was used to synthesize cDNA from $1 \mu \mathrm{g}$ of total RNA, according to the manufacturer's protocol. The house keeping gene $\beta$-actin was used as a constitutive control for normalization. Reactions were carried out in the presence of $200 \mathrm{nM}$ of specific primers. Primers were designed using Primer3 software (The Whitehead Institute, http://frodo.wi.mit.edu/cgi-bin/primer3/primer3_www.cgi) and are shown in Table $\mathbf{2}$.

The specificity of the primers was confirmed by running the products of Polymerase Chain Reaction (PCR) amplification in a $2 \%$ agarose gel against molecular weight markers (product sizes are shown in Table 1) and by a BLAST software-assisted search of a non-redundant nucleotide sequence database (National Library of Medicine, Bethesda, MD). After each PCR run, melting curves were performed to assure no contamination in the individual wells of PCR plates [6]. Wells showing more than one peak were excluded from subsequent analysis.

To assess whether a high-fat treatment modified the expression of $\beta$-actin, PCR with serial dilutions of this housekeeping gene was performed. PCR reactions were carried out in an AbiPrism 7300 (Applied Biosystems, Foster City, CA). The PCR reaction conditions were $15 \mathrm{~min}$ at $95 \mathrm{C}$ followed by 40 cycles of $15 \mathrm{sec}$ at $94 \mathrm{C}, 30 \mathrm{sec}$ at $60 \mathrm{C}$ and $30 \mathrm{sec}$ at $72 \mathrm{C}$. Fluorescence data were collected during the $72 \mathrm{C}$ step. Serial dilutions of cDNA from control pituitaries were used to perform calibration curves in order to determine amplification efficiencies. For the primers used there were no differences between transcription efficiencies, the amount of initial cDNA in each sample being calculated by the $2^{-\Delta \Delta C t}$ method [6]. All samples were analyzed in triplicate and in

Table 2. Sequence of the Primers Used for Real-Time PCR

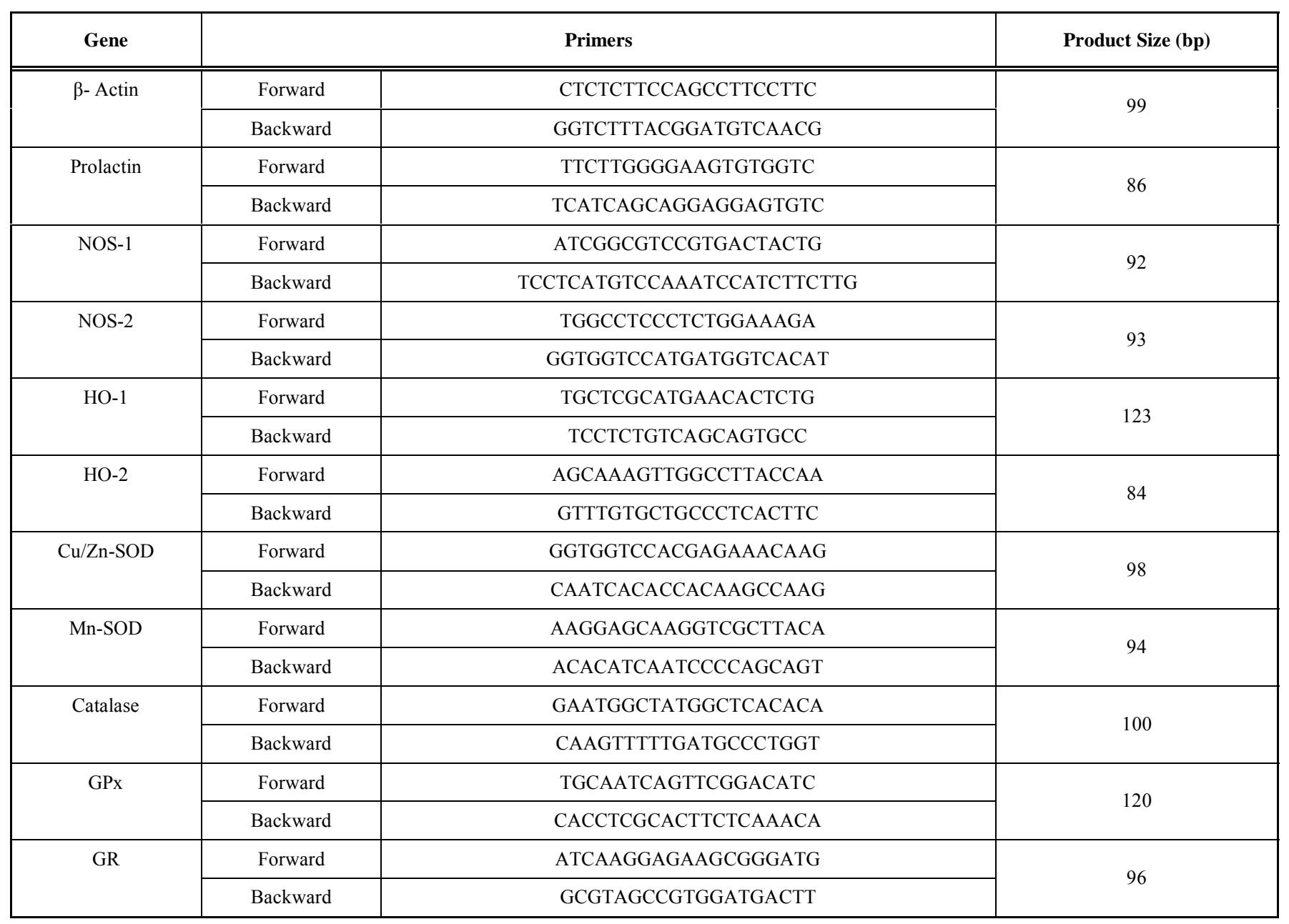


three different measures. Fractional cycle at which the amount of amplified target becomes significant $(\mathrm{Ct})$ was automatically calculated by the PCR device. When tested brain or in muscle tissue no expression of prolactin gene was observed (results not shown).

Statistical analysis of results was performed by a Student's t test, a one-way analysis of variance (ANOVA) or a two-way factorial ANOVA, as stated. For the factorial ANOVA, the analysis included assessment of the group effect (i.e. the occurrence of differences in mean values between normal and high-fat diet rats), of time-of-day effects (the occurrence of daily changes) and of the interaction between the two factors (diet and time, from which inference about differences in timing and amplitude could be obtained). Post-hoc Bonferroni's multiple comparison tests in a one way ANOVA were then employed to show which time points were significantly different within each experimental group to define existence of peaks. $\mathrm{P}$ values lower than 0.05 were considered evidence for statistical significance.

\section{RESULTS}

The correlation between anterior pituitary prolactin gene expression and plasma prolactin levels in rats (data from [1]) fed a normal or a high-fat diet is depicted in Fig. (1). In rats feeding a normal diet the maximum in prolactin gene expression, occurring at early scotophase $(2100 \mathrm{~h})$, anticipated by about $3 \mathrm{~h}$ the maximum in plasma prolactin

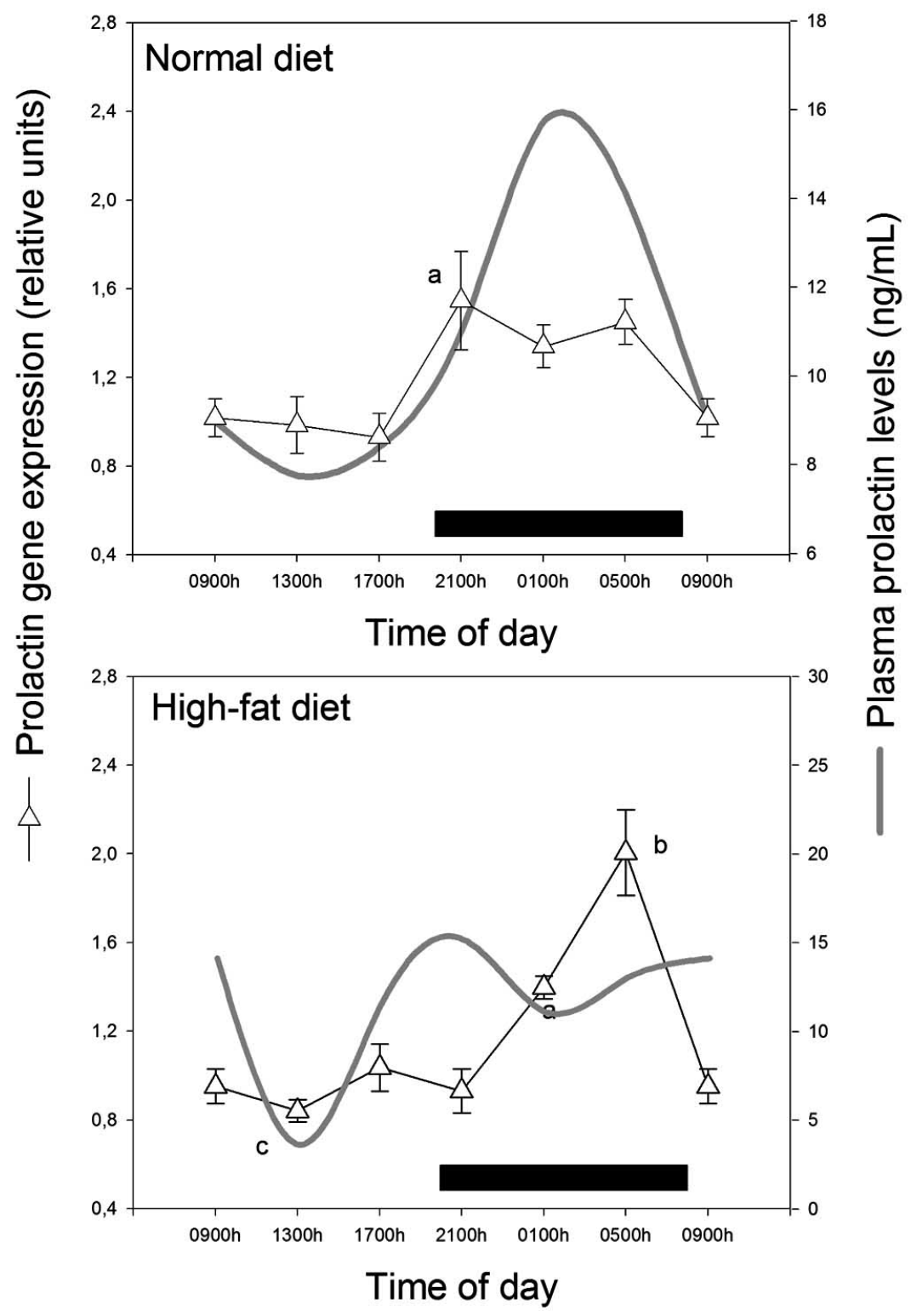

Fig. (1). Effect of a high-fat diet on 24-h changes in plasma prolactin levels and prolactin gene expression in the anterior pituitary of rats. Groups of 6-8 rats were killed by decapitation at 6 different time intervals throughout a $24 \mathrm{~h}$ cycle. mRNA levels encoding prolactin were by triplicate real-time PCR analyses of RNA samples as described in the text. Shown are the means \pm SEM. Prolactin levels are reproduced from a previous publication [1]. Letters denote significant differences in a one-way ANOVA followed by a Bonferroni's multiple comparison test, as follows: ${ }^{\mathrm{a}} \mathrm{p}<0.05$ vs. $1700 \mathrm{~h} ;{ }^{\mathrm{b}} \mathrm{p}<0.01 \mathrm{vs.} 0900,11300,1700$ and $2100 \mathrm{~h}$. 
levels (Fig. 1, upper panel). Such coordination became disrupted in high-fat fed rats, as shown by a delay in prolactin gene expression to the second part of the scotophase as well as by the abolition of peak plasma prolactin levels at night reported previously [1] (Fig. 1, lower panel). Hence a disruption of prolactin biosynthetic mechanisms at early night appeared to occur in high-fat fed rats.
Fig. (2) depicts the relative expression of anterior pituitary NOS-1 and NOS-2 genes in both groups of animals. NOS-1 mRNA levels did not exhibit significant 24-h variations while those of NOS-2 peaked at the early light phase of daily photoperiod $(\mathrm{F}=11.5, \mathrm{p}<0.001$ for time as a main factor in factorial ANOVA). A high-fat diet augmented NOS-2 mRNA by $37 \%(\mathrm{~F}=11.8, \mathrm{p}<0.001)$ without modifying that of NOS-1 significantly (Fig. 2).
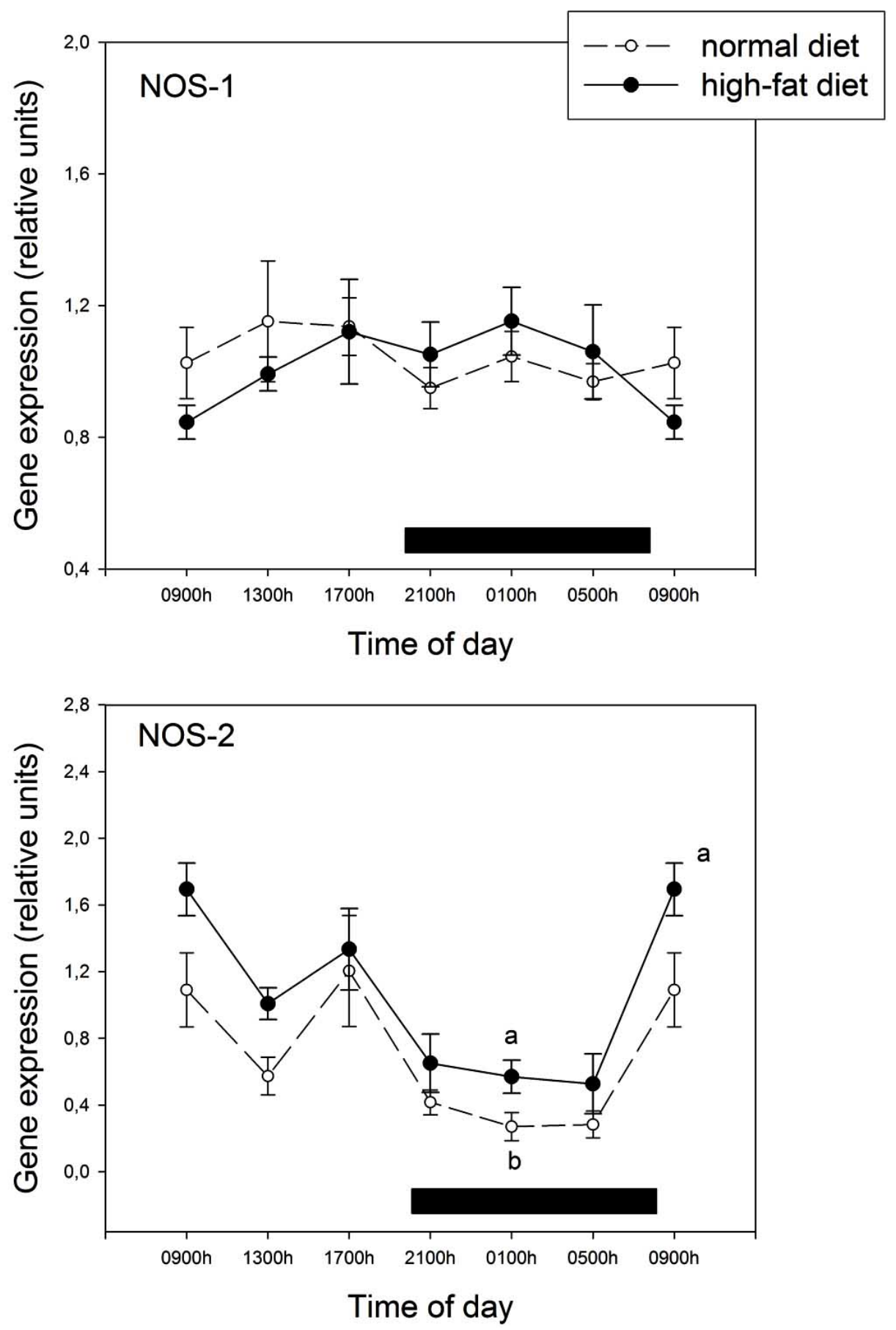

Fig. (2). Effect of a high-fat diet on 24-h changes in expression of mRNA for NOS-1 and NOS-2 in the anterior pituitary of rats. Groups of 68 rats were killed by decapitation at 6 different time intervals throughout a $24 \mathrm{~h}$ cycle. mRNA levels encoding the NOS-1 and NOS-2 enzymes were measured as described in the text. Shown are the means \pm SEM of mRNA determination as measured by triplicate real-time PCR analyses of RNA samples. Letters denote significant differences in a one-way ANOVA followed by a Bonferroni's multiple comparison test, as follows: ${ }^{\mathrm{a}} \mathrm{p}<0.01$ vs. 2100,0100 and $0500 \mathrm{~h} ;{ }^{\mathrm{b}} \mathrm{p}<0.05$ vs. 0900 and $1700 \mathrm{~h}$. For further statistical analysis, see text. 

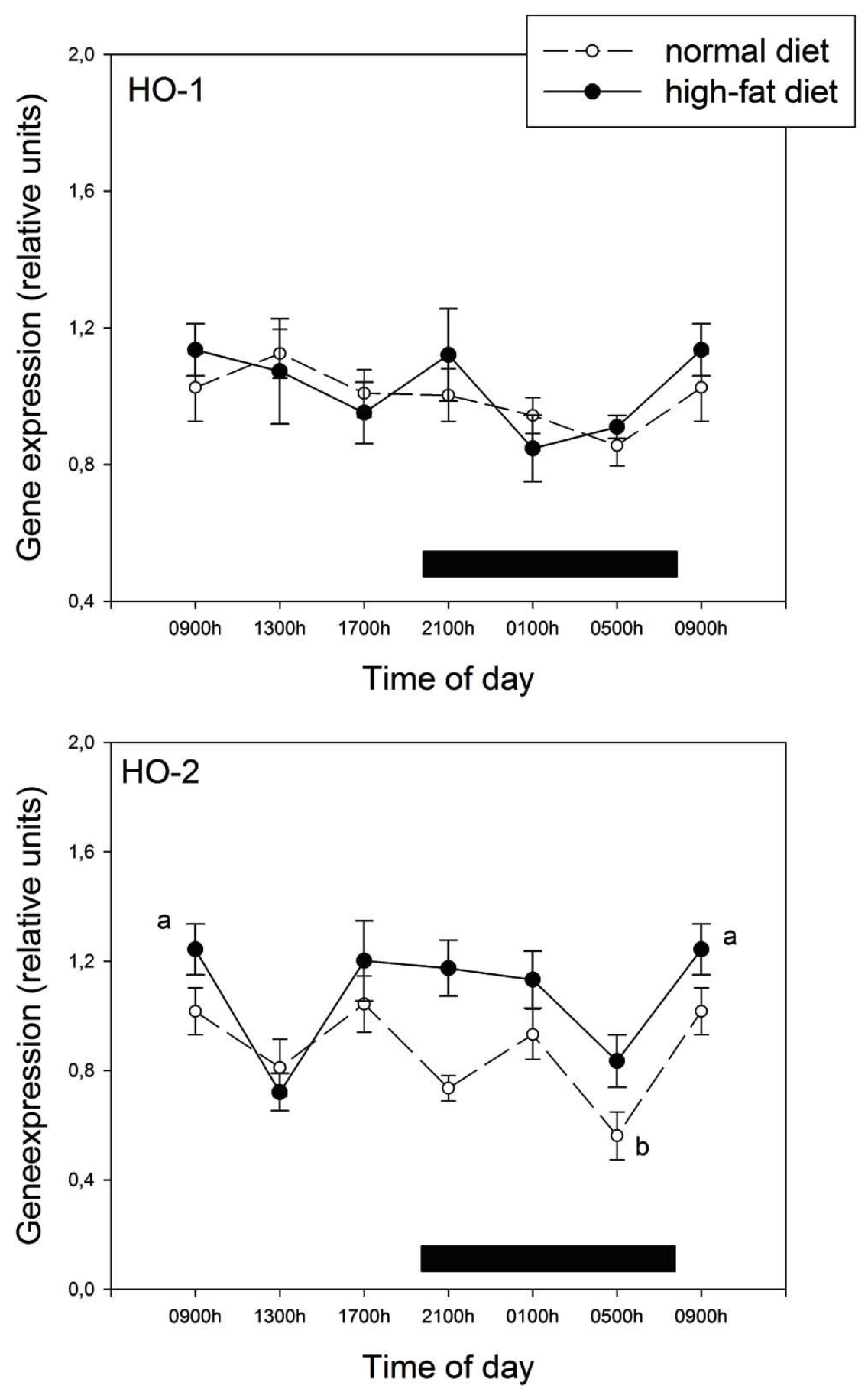

Fig. (3). Effect of a high-fat diet on 24-h changes in expression of mRNA for HO-1 and HO-2 in the anterior pituitary of rats. Groups of 6-8 rats were killed by decapitation at 6 different time intervals throughout a 24 h cycle. mRNA levels encoding HO-1 and HO-2 enzymes were measured as described in the text. Shown are the means \pm SEM of mRNA determination as measured by triplicate real-time PCR analyses of RNA samples. Letters denote significant differences in a one-way ANOVA followed by a Bonferroni's multiple comparison test, as follows: ${ }^{\mathrm{a}} \mathrm{p}<0.05$ vs. $1300 \mathrm{~h} ;{ }^{\mathrm{b}} \mathrm{p}<0.05$ vs. $0900 \mathrm{~h}$ and $1700 \mathrm{~h}$. For further statistical analysis, see text.

Anterior pituitary gene expression of HO-1 and HO-2 is depicted in Fig. (3). As shown by the analysis of time as a main factor in the factorial ANOVA, HO-1 gene expression did not exhibit 24-h variations whereas that of HO-2 changed significantly as a function of time of day $(\mathrm{F}=7.0, \mathrm{p}<0.001)$. The high-fat diet augmented mRNA levels for HO-2 $(\mathrm{F}=11.8, \mathrm{p}<0.001)$ without modifying HO-1 significantly (Fig. 3). A disruption in 24-h rhythmicity of HO-2 gene expression was apparent in high-fat fed rats, with a trend to maintain high levels during most of the scotophase.

Anterior pituitary mRNA levels for $\mathrm{Cu} / \mathrm{Zn}-\mathrm{SOD}, \mathrm{Mn}$ SOD and catalase genes are shown in Fig. (4). For the three antioxidant enzymes tested, mRNA expression in controls exhibited significant 24-h variations, with maxima at the light phase of daily photoperiod $(\mathrm{p}<0.0001)$. In high-fat fed rats these diurnal rhythms were disrupted, with a trend to 

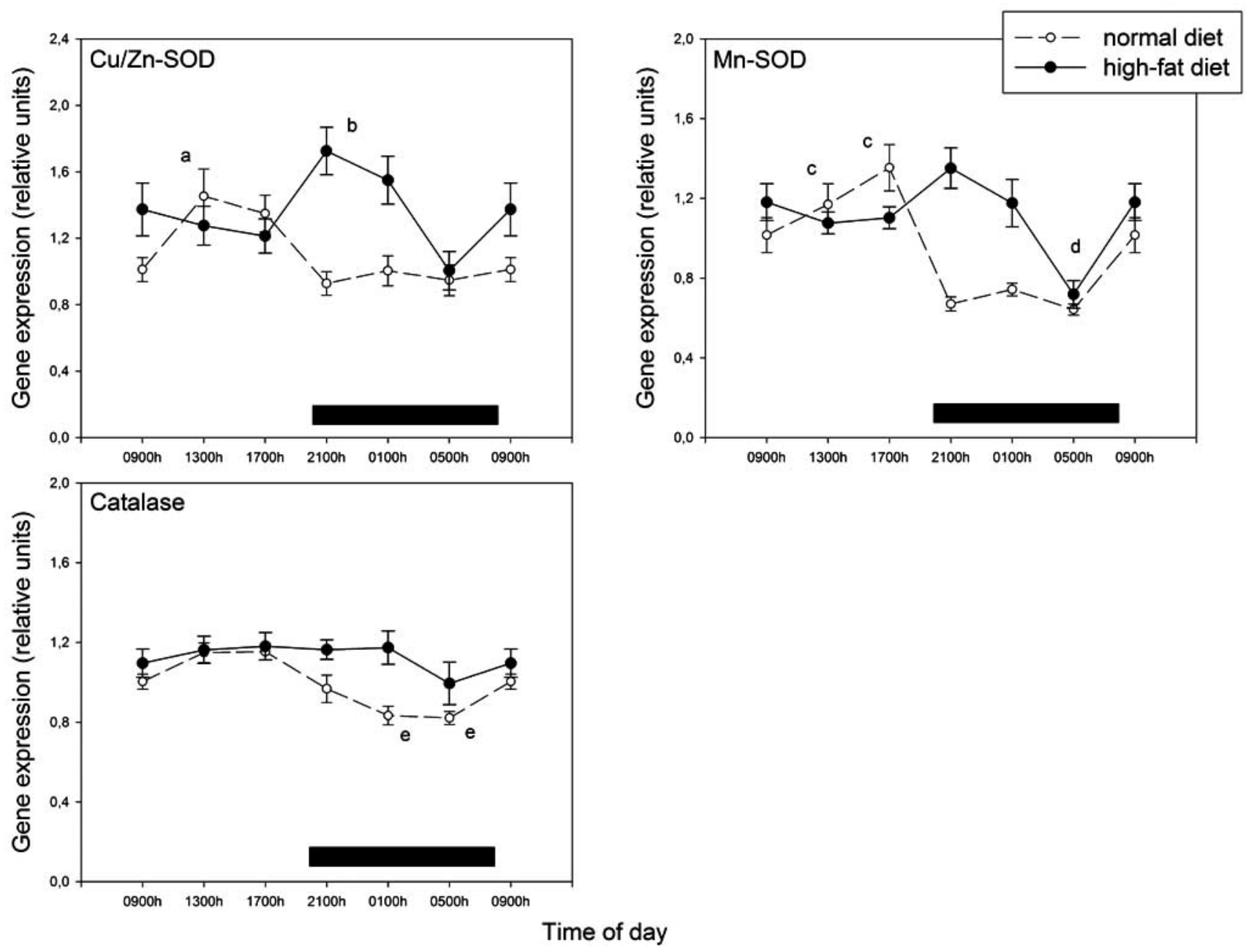

Fig. (4). Effect of a high-fat diet on 24-h changes in expression of mRNA for $\mathrm{Cu} / \mathrm{Zn}-\mathrm{SOD}, \mathrm{Mn} / \mathrm{SOD}$ and catalase in the anterior pituitary of rats. Groups of 6-8 rats were killed by decapitation at 6 different time intervals throughout a $24 \mathrm{~h}$ cycle. mRNA levels encoding Cu/Zn-SOD, $\mathrm{Mn} / \mathrm{SOD}$ and catalase enzymes were measured as described in the text. Shown are the means \pm SEM of mRNA determination as measured by triplicate real-time PCR analyses of RNA samples. Letters denote significant differences in a one-way ANOVA followed by a Bonferroni's multiple comparison test, as follows: ${ }^{\mathrm{a}} \mathrm{p}<0.01 v s .0500 \mathrm{~h} ;{ }^{\mathrm{b}} \mathrm{p}<0.05 v s .2100 \mathrm{and} 0500 \mathrm{~h} ;{ }^{\mathrm{c}} \mathrm{p}<0.01 \mathrm{vs} .2100,0100$ and $0500 \mathrm{~h}$; ${ }^{\mathrm{d}}$ $\mathrm{p}<0.02$ vs. 0900, 1700, 2100 and $0100 \mathrm{~h} ;{ }^{\mathrm{e}} \mathrm{p}<0.05$ vs. 1300 and $1700 \mathrm{~h}$. For further statistical analysis, see text.

maintain high levels of expression at early scotophase (Fig. 4).

As shown in Fig. (5), anterior pituitary mRNA levels for the antioxidant enzymes GPx and GR peaked at the first part of scotophase in controls with a significant phase delay in high-fat fed rats. The factorial ANOVA indicated a significant depressive effect of the high-fat diet on GPx and GR gene expression (GPx: F= 5.28, $\mathrm{p}<0.03$; GR: $F=14.3$, $\mathrm{p}<0.001$ ), occurring mainly at the first part of scotophase (Fig. 5).

\section{DISCUSSION}

Foregoing results indicate that the disrupted coordination between prolactin gene expression and prolactin release found in high-fat fed rats comes along with a disturbed expression of redox enzyme genes in the anterior pituitary. In particular, adenohypophysial mRNA levels for NOS-2 and $\mathrm{HO}-2, \mathrm{Cu} / \mathrm{Zn}$ - and $\mathrm{Mn}-\mathrm{SOD}$ and catalase augmented in high-fat fed rats, whereas those of GPx and GR decreased. Disruption of 24-h rhythmicity of gene expression of HO-2, $\mathrm{Cu} / \mathrm{Zn}-\mathrm{SOD}, \mathrm{Mn}-\mathrm{SOD}$, catalase, GPx and GR was apparent in high-fat fed rats.

Obesity is a state of chronic oxidative stress, which is a major mechanism underlying the development of comorbidities in obesity [7]. Oxidative stress is associated with several indices of adiposity and a low antioxidant defense. In the same animals we previously reported significant changes in 24-h rhythmicity of pituitary hormone release including prolactin [1]. The present results on the disrupted coordination between prolactin gene expression and prolactin release in obese rats can be interpreted in terms of the significant oxidative stress brought about in the anterior pituitary by the high-fat diet.

In this respect, NO presumably plays a major role $[3,4]$. $\mathrm{NO}$ is synthesized by NO-1 (constitutive) and NOS-2 (inducible) NOS, which are expressed in the pituitary gland [8,9]. NOS-1 are responsible for low and persistent 

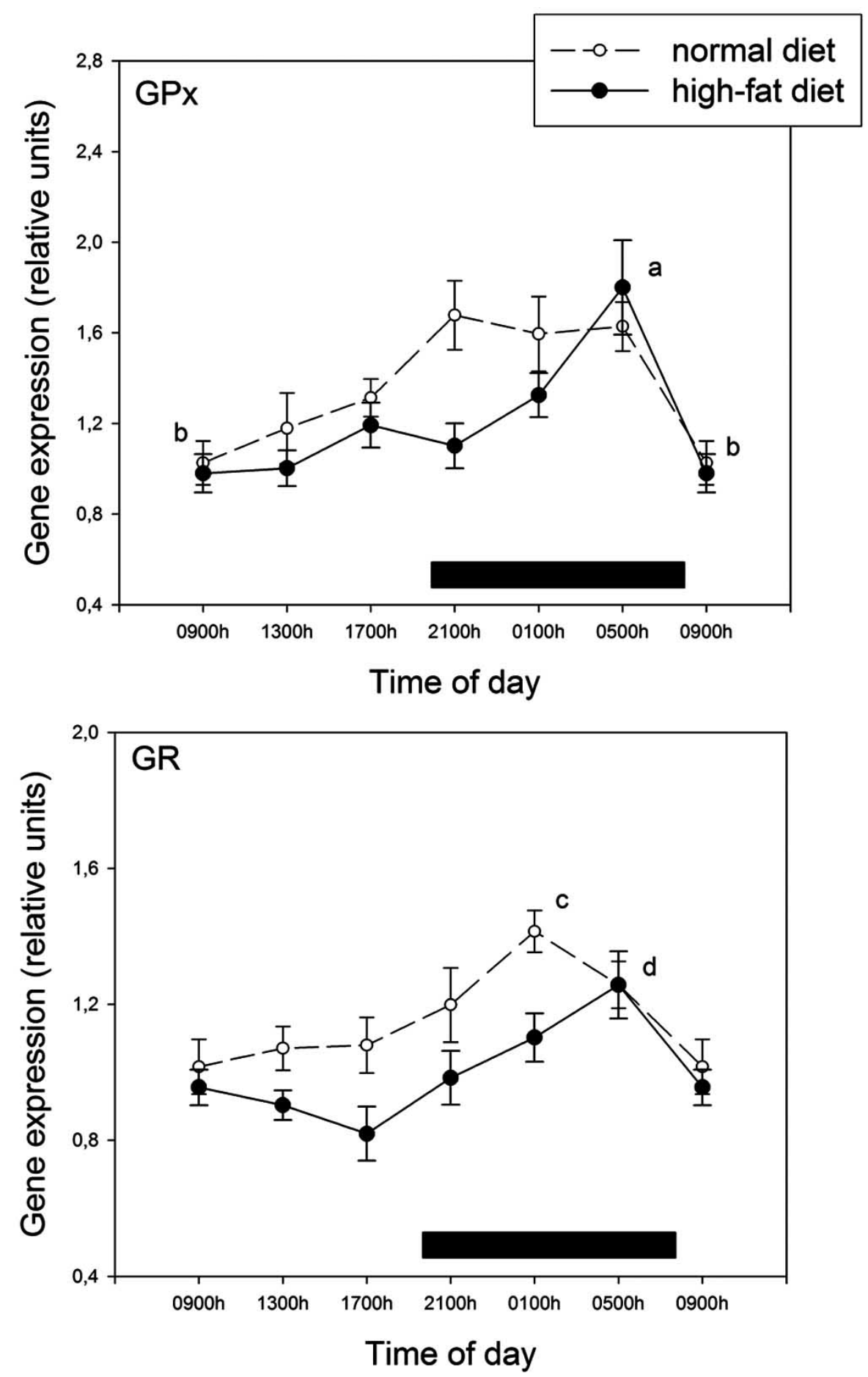

Fig. (5). Effect of a high-fat diet on 24-h changes in expression of mRNA for GPx and GR in the anterior pituitary of rats. Groups of 6-8 rats were killed by decapitation at 6 different time intervals throughout a $24 \mathrm{~h}$ cycle. mRNA levels encoding GPx and GR enzymes were measured as described in the text. Shown are the means \pm SEM of mRNA determination as measured by triplicate real-time PCR analyses of RNA samples. Letters denote significant differences in a one-way ANOVA followed by a Bonferroni's multiple comparison test, as follows: ${ }^{\mathrm{a}} \mathrm{p}<0.02$ vs. 0900, 1300, 1700 and $2100 \mathrm{~h} ;{ }^{\mathrm{b}} \mathrm{p}<0.05$ vs. 2100 and $0500 \mathrm{~h} ;{ }^{\mathrm{c}} \mathrm{p}<0.05$ vs. $0900 \mathrm{~h} ;{ }^{\mathrm{d}} \mathrm{p}<0.05$ vs. 1300 and $1700 \mathrm{~h}$. For further statistical analysis, see text.

concentrations of NO, typical of normal situations. The present results indicate that the high-fat diet caused an upregulation of pituitary NOS-2 expression, presumably resulting in high levels of NO that could be instrumental in the disruption of prolactin release mechanisms herein reported. Indeed, although submicromolar concentrations of
NO can protect anterior pituitary cells from cytotoxic agents, long-term exposure of ptuitary cells to high concentrations of NO induces cellular damage [10].

Because reactive oxygen species (ROS) generation is a continuous and physiological phenomenon, cells possess 
efficient antioxidant systems that protect them from oxidative damage (for recent reviews, see [11-13]). These defense systems are thought to prevent free radicals from causing irreparable damage by reacting with lipids, proteins and nucleic acids and are controlled in vivo by a wide spectrum of enzymatic [14] and non-enzymatic systems [15]. In the anterior pituitary almost all redox pathway enzymes have been described; however, there is scarce information on the existence of circadian rhythms in enzyme activity or gene expression in this tissue.

HO has an important role in controlling the redox state of the cell by functioning as a rate-limiting enzyme in the heme degradation process [11]. The oxidative degradation of heme, which results in the formation of equimolar amounts of carbon monoxide $(\mathrm{CO})$ and biliverdin, is catalyzed by the microsomal enzyme HO. Biliverdin and bilirubin are known to be potent antioxidants [11]. Three isoforms of HO have been identified. HO-1 is an inducible isoform that is responsive to various stimuli, including oxidative stress. HO-2 is a constitutive isoform that is less inducible by oxidative stress. The remaining isoform, HO-3, has been less well characterized [11]. The anterior pituitary displays both HO-1 and HO-2 mRNA proteins and enzymatic activity, explaining the high CO production rate that the gland has [16-19].

In the present study, and concomitant with the disrupting effect that the high-fat diet has on prolactin secretion, an increase in HO-2 expression was observed, mainly at the first part of scotophase, when the oxidative damage appears to be maximal. The results suggest that an overexpression of HO-2 gene is counteracting the oxidative damage caused by excess NO.

The detoxification of ROS in cells involves the cooperative action of intracellular antioxidant enzymes, among them $\mathrm{Cu} / \mathrm{Zn}-\mathrm{SOD}$ that is cytosolic, Mn-SOD that is mitochondrial, and catalase that is present in peroxisomes [20]. In addition, GPx and GR help to maintain adequate levels of reduced glutathione, a major antioxidant defense of the cells. The changes in redox enzyme mRNA expression brought about by the high-fat diet in the present study can be interpreted in terms of a compensatory increase caused by the augmented oxidative load (i.e., $\mathrm{Cu} / \mathrm{Zn}$ - and $\mathrm{Mn}$ - SOD and catalase) together with a depression of enzyme gene expression caused by excess ROS generation (i.e., GPx and GR). Since ROS play a role in cellular signalling processes, including transcription factors activities such NF-kB and AP1 , the increase of free radicals caused by the high-fat diet would allow modulation of redox-sensitive transcription factors, which could in turn regulate gene transcription [20,21].

There are several limitations to the present study. First, further studies are needed to shed light on the mechanisms that explain high-fat diet effect on redox enzyme gene expression. In particular, Western blotting analysis of enzyme protein levels will be useful in this respect.

Second, whether the altered circadian rhythms found are due to the high fat content of the diet, to elevated caloric intake, or to some indirect result of body weight gain, obesity and fat deposition should be further examined. The study of rats pair-fed the high-fat diet but matched to the caloric input of the rats fed the control diet could yield valuable information on this point.

Third, further examination is needed to assess whether acute overfeeding immediately disrupted diurnal rhythmicity, as shown for cardiovascular parameters in rabbits [22]. An earlier measurement of gene expression at a time before body weights diverged significantly could be useful in this respect.

Another limitation is given by the method of sampling. A pulsatile release exists for prolactin release and such ultradian variations are not measurable with the experimental approach used. Finally, further experiments are needed to assess whether the changes in amplitude as well in timing of 24-h rhythms discussed herein can be attributed to an effect on the SCN or to a masking effect on some output(s) of the clock. The data only draw a correlation and the causality of the changes observed can only be speculated upon. In future studies it will be important to establish actual ROS production in the hypophysis of obese rats and whether by blocking or stimulating ROS alteration in circadian profile of prolactin secretion is obtained.

\section{CONCLUSION}

The results support the conclusion that the disrupted coordination between prolactin gene expression and prolactin release in high-fat fed rats comes along with a disturbed expression of redox enzyme genes in the anterior pituitary.

\section{ABBREVIATIONS}

$\begin{array}{ll}\text { ANOVA } & =\text { Analysis of variance } \\ \mathrm{CO} & =\text { Carbon monoxide } \\ \mathrm{GPx} & =\text { Glutathione peroxidase } \\ \mathrm{GR} & =\text { Glutathione reductase } \\ \mathrm{HO} & =\text { Heme oxygenase } \\ \mathrm{PCR} & =\text { Polymerase chain reaction } \\ \mathrm{NOS} & =\text { Nitric oxide synthase } \\ \mathrm{SOD} & =\text { Superoxide dismutase }\end{array}$

\section{ACKNOWLEDGEMENTS}

This work was supported by grants from Mutua Madrileña Foundation and Eugenio Rodríguez Pascual Foundation, Madrid, Spain, and Agencia Nacional de Promoción Científica y Tecnológica, Argentina (PICT 200701045). DPC is a Research Career Awardee and PAS is a postdoctoral fellow from the Argentine Research Council (CONICET).

\section{REFERENCES}

[1] Cano P, Jimenez-Ortega V, Larrad A, Reyes Toso, CF, Cardinali DP, Esquifino AI. Effect of a high-fat diet on 24-h pattern of circulating levels of prolactin, luteinizing hormone, testosterone, corticosterone, thyroid-stimulating hormone and glucose, and pineal melatonin content, in rats. Endocrine 2008; 33: 118 
[2] Buijs RM, Scheer FA, Kreier F, et al. Chapter 20: Organization of circadian functions: interaction with the body. Prog Brain Res 2006; 153: 341.

[3] Velardez MO, De Laurentiis A, del Carmen DM, et al. Role of phosphodiesterase and protein kinase $\mathrm{G}$ on nitric oxide-induced inhibition of prolactin release from the rat anterior pituitary. Eur $\mathbf{J}$ Endocrinol 2000; 143: 279.

[4] Quinteros FA, Poliandri AH, Machiavelli LI, Cabilla JP, Duvilanski $\mathrm{BH}$. In vivo and in vitro effects of chromium VI on anterior pituitary hormone release and cell viability. Toxicol Appl Pharmacol 2007; 218: 79.

[5] Institute of Laboratory Animal Resources CoLSNRC: Guide for the Care and Use of Laboratory Animals. Washington, D.C.: National Academy Press 1996.

[6] Livak KJ, Schmittgen TD. Analysis of relative gene expression data using real-time quantitative PCR and the $2-\Delta \Delta \mathrm{Ct}$ method. Methods 2001; 25: 402.

[7] Vincent HK, Innes KE, Vincent KR. Oxidative stress and potential interventions to reduce oxidative stress in overweight and obesity. Diabetes Obes Metab 2007; 9: 813.

[8] Ceccatelli S. Expression and plasticity of NO synthase in the neuroendocrine system. Brain Res Bull 1997; 44: 533.

[9] Vankelecom H, Matthys P, Denef C. Involvement of nitric oxide in the interferon-gamma-induced inhibition of growth hormone and prolactin secretion in anterior pituitary cell cultures. Mol Cell Endocrinol 1997; 129: 157.

[10] Machiavelli LI, Poliandri AH, Quinteros FA, Cabilla JP, Duvilanski BH. Reactive oxygen species are key mediators of the nitric oxide apoptotic pathway in anterior pituitary cells. Nitric Oxide 2007; 16: 237.

[11] Mancuso C, Scapagini G, Curro D, et al. Mitochondrial dysfunction, free radical generation and cellular stress response in neurodegenerative disorders. Front Biosci 2007; 12: 1107.

[12] Radak Z, Kumagai S, Taylor AW, Naito H, Goto S. Effects of exercise on brain function: role of free radicals. Appl Physiol Nutr Metab 2007; 32: 942.
[13] Reynolds A, Laurie C, Mosley RL, Gendelman HE. Oxidative stress and the pathogenesis of neurodegenerative disorders. Int Rev Neurobiol 2007; 82: 297

[14] Inal ME, Kanbak G, Sunal E. Antioxidant enzyme activities and malondialdehyde levels related to aging. Clin Chim Acta 2001; 305: 75 .

[15] Wang JY, Wen LL, Huang YN, Chen YT, Ku MC. Dual effects of antioxidants in neurodegeneration: direct neuroprotection against oxidative stress and indirect protection via suppression of gliamediated inflammation. Curr Pharm Des 2006; 12: 3521.

[16] Alexandreanu IC, Lawson DM. Heme oxygenase in the rat anterior pituitary: immunohistochemical localization and possible role in gonadotropin and prolactin secretion. Exp Biol Med (Maywood) 2003; $228: 64$.

[17] Rivier C. Role of nitric oxide and carbon monoxide in modulating the activity of the rodent hypothalamic-pituitary-adrenal axis. Front Horm Res 2002; 29: 15.

[18] Navarra P, Grossman AB. The heme oxygenase-carbon monoxide pathway in the control of neuroendocrine function. Front Horm Res 2002; 29: 108 .

[19] Poliandri AH, Esquifino AI, Cano P, et al. In vivo protective effect of melatonin on cadmium-induced changes in redox balance and gene expression in rat hypothalamus and anterior pituitary. J Pineal Res 2006; 41: 238.

[20] Rodriguez C, Mayo JC, Sainz RM, et al. Regulation of antioxidant enzymes: a significant role for melatonin. J Pineal Res 2004; 36: 1.

[21] Lezoualc'h F, Sparapani M, Behl C. N-acetyl-serotonin (normelatonin) and melatonin protect neurons against oxidative challenges and suppress the activity of the transcription factor NFkappaB. J Pineal Res 1998; 24: 168.

[22] Carroll JF, Thaden JJ, Wright AM, Strange T. Loss of diurnal rhythms of blood pressure and heart rate caused by high-fat feeding. Am J Hypertens 2005; 18: 1320.

Received: June 24, 2009

Revised: October 09, 2009

Accepted: October 09, 2009

(C) Cano et al.; Licensee Bentham Open.

This is an open access article licensed under the terms of the Creative Commons Attribution Non-Commercial License (http://creativecommons.org/licenses/by$\mathrm{nc} / 3.0 /$ ), which permits unrestricted, non-commercial use, distribution and reproduction in any medium, provided the work is properly cited. 